\title{
An exploratory study of four factors which affectsocial workers' professional practice in Libyan human service organzations
}

\author{
Abdelrazag masud .phd \\ Department of social work university of Tripoli libya
}

\begin{abstract}
Leadership and governance are critical to human service organizations. In Libya, the professional practice of social workers within such organizations is influenced by four factors: social workers' morale, their human relationships within the organization, their relationship with the manager, and organizational control within the organization. Thisexploratory study considers 10 social organizations and rehabilitation centers in Tripoli with 111 social workers as participantsconducted from July to September 2015. Results indicate thateffective leadership and sound governance in human service organizations are critical to the professional practice of social workers.
\end{abstract}

Keywords: -Management, leadership, and organizational change; workforce/workplace issues inhuman service organizations

\section{INTRODUCTION}

'Human service organizations play a pivotal role in the lives of people' (Hasenfeld, 2010, p.9). Indeed, according to Hasenfeld, these organizations can both enhance the lives of community members but can also be seen as overly bureaucratic and rigid. Similarly, human service organizations can enhance staff members' sense of commitment and dedication but also constrain them 'from serving their clients in accordance with their professional and personal norms and values' $(2010, \mathrm{p} 11)$.These comments have validity in both developed and developing countries in which human service organzations operate.In the midst of the upheaval which has taken place in Libyan society since 2011, the intention of this study is to explore social workers' professional practice within human service organizations. To do this, the researchers will focus on four factors originally developed by Masud using a sociological and managerial perspective which were used in an earlier study (1999). These include morale, human relationships, managerial style, which includes leadership, and organizational control or governance within the social work profession. There is an overall lack of research on social organizations and rehabilitation centers in Libya where preliminary evidence points to challenging and increasingly complex work environments for social workers generally (Masud, 1999). This research seeks to address this gap in knowledge, with a particular focus on social organizations and rehabilitation centers, with the intention to better understand this area of professional practice. Therefore, an exploration of these four factors will be conducted, from the perspective of practitioners themselves, to gain an effective understanding of the societal and governance issues within Libyan human service organizations.

\section{Literature review}

Libya is an Arabic Muslim country. According to theStatistical Book of Libya, the official population was 5.702 million in 2010 and the capital, Tripoli, had a population of 1.067 million (Bureau of Statistics and Census, 2010). Considerable political changes have taken place in Libya since 2011. There are three governments in different regions of Libya, including two Ministries of Social Affairs. The governments have a significant level of control over social affairsin the regions over which they have political control.Libyans have experienced considerable difficulties in adjusting to this new reality.Currently, due to these political changes,largely new social problems have evolvedwhich includeincreasing social inequalities, the creation of new forms of social exclusion, and demographic changes, such as large numbers of displaced people coming to Tripoli.These social problems are reflected in widening social gaps and increased inequality as well as in the weakening of relationships and changes in function of informal human relationships, along with upheaval and insecurity and the breakdown of the state in terms of bureaucratic control.In most instances in Libya, the practice of the social work profession is not easy, as is the case in other developed and developing countries (Calma \& Priday, 2011; Collins, 2008; Tham \& Meagher, 2009; Thompson \& Thompson, 2008). This is because of several matters, including the social work profession's relationship to societal changes, which must take into consideration changes in professional practice.In Libya, the social organizations' and rehabilitation centers' environment, which could be considered unstable in the last few years, has been subject to frequent changes as financial support from government has been reduced.Due to the absence of research, and so based on 
interviews conducted with respondents in this study, there appears to be general agreement on these problemsamongst social workers in Libya.These changes have been accompanied by a decrease in the integration of social workerswhich in turn has exacerbated retention and recruitment problems. The social work profession is influenced by social, cultural, economic, political, and demographic factors that impact onwelfare organizations (Ginsberg, 2008; Rank \& Hutchison, 2000; Sowers \& Rowe, 2007) and place limitations on social workers' practices (Benish, 2010; Iversen, 2004; Shier \& Graham, 2013). In light of the changes mentioned above in Libyan society,it is helpful to study the nature of leadership and the governance structure within which social workers function that appear to have changed since 2011.It is important to acknowledge that individuals and organizationsarea microcosm of the wider society of which they are a part (Fook \& Gardner, 2007; Itzin \& Newman, 2005; Sue \& Sue, 2013). Therefore, the nature of practice in social organizations and rehabilitation centers needs to be seen from the perspective of thatsociety. Indeed the social organizations and rehabilitation centers in Libyaare a microcosm of the social and political changes which currently exist in Libyan society, which include the dramatic changes in the Libyan way of life during times of recent militant confrontation.Social workers, as members of such a society, bring to their organization all of these influences which have an impact directly on their professional practice and which illustrate the enormous challenges facing their practice (Johnson \& Yanca, 2010; Kondrat, 2002). Social workers are expected to practice according to thesocial work code of values and ethics (Kirst-Ashman, 2013). In 2007, there was an attempt by the Libyan Social Workers'Guild to define a Libyan framework for a code of ethics, but this was not successful due to circumstances beyond its control. Therefore, currently social work professional practice within workplaces is not based on a formalised social work code of ethics, but on personal knowledge, values and skills. Social workers as individuals adopt a certain set of values and ethics from their cultural and social contexts, such as their family, religion and cultural community (Barsky, 2010; Masud, 2011). In Libyan society, cultural and social contexts are not a personal matter of choice; they are considered as a family duty. This understanding, which is strongly influenced by family, has a big role to play in teaching its members to espouse local cultural values. Commitment to this understanding is a high priority in Libyan society. In most cases, it acts to oblige or force its members to espouse specific practices that are consistent with the values of the society. This study considered a sample of social workers from four residentialsocial organizations, or welfare centers, and six residential and day care rehabilitationcenters for handicapped clientswhich are part of the Public Authority for Social Solidarity Fundin the city of Tripoli, the capital of Libya.Thesocial organizationsand rehabilitation centers in Libya interact with and are dependent upon the society in which they operate (Austin, 2002; Shanks, Lundstrom \& Wiklund, 2015; Skyttner, 2002; Teater, 2011; Zastro \& Kirst-Ashman, 2012). From this perspective, the social organizations and rehabilitation centers can beseen as elements within a larger society.In order to survive,these organizations have to achieve an appropriate relationship with the society in which they operate (G. Morgan, 2010)as suchorganizations do not stand in isolation. The surrounding environment, which may include political, economic, and social changes, influences thesesocial organizations (Michael \& Femida, 2015; Schmid, 2004). It is important to note that each social worker in Libya is a member of more than one system within society,including family, tribe, local community, as a citizen in society and as a member inthe workplace. Indeed, the boundaries between these systems are porous. Social workers bring with them to the workplace their personal experiences, values, beliefs, attitudes, problems, their morale, relationships and family issues, and each of these shapes and affects social workers' practice both positively and negatively (Bogo, 2006). Professional practice standards for social workers mean that they should 'consistently act in a principled and acceptable manner' (AASW, 2013, p.10). These standards refer to the knowledge, professional values and skills used by social workers within any human service organization. However, there is little understanding aboutwhat such standards mean for social workers' practice in a Libyan context. Similarly, leadership and governance are critical to the organizational performance of these social organizations. But what is the nature of leadership and governance under the extraordinary circumstances which currently prevail in Libya? Factors that impact on organizational performance are multifaceted (Popa, 2012). The current researchers have chosen to investigate social workers' professional practice as it relates to four factors, these being the social workers' morale, their human relationships within the organization, their relationship with the manager, and the organizational control within the organization. This piece of research is exploratory and uses content analysis as a means to draw preliminary conclusions.

\section{Definition of the four factors}

At this point, it is important to define and operationalize the four factors to determine the impact they have on the performance of social organizations in Libya.

First: the state of morale

Rauktis and Koeske consider employees' morale to be a delicate factor that affects job performance (1994). A low level of morale results in repeated absenteeism and tardiness, inattention to work, noncompliance, 
and interpersonal frictions, which is not aneffective way to run an organization (Kadushin \& Harkness, 2014).Morale is the degree of feeling related to spirit and enthusiasm, and degree of cooperation among workers (Mascha, 2007). In this research, the concept of morale is used to describe social workers who are working together and refers to the general environment around professional practice. If they appear to feel enthusiastic and optimistic about their practice, the social workers' morale will be high. If they are showing their dissatisfaction, are upset and anxious, and there prevails among them a spirit of criticism,vitriol and instability, these manifestations of reactions can be taken as a state of low morale. The framework applied in this research is to consider the morale factor by exploring the following attitudes: satisfaction with the regulations and instructions; job satisfaction; the work routine and boredom; cooperation and understanding among social workers; willingness to move to another workplace; and encouraging incentives.

\section{Second: human relationships}

The human interactions within social organizations require that a certain style of relationshipis appropriate (Payne, 2009).A dynamic, interpersonalconnection between individuals includes how they think about, feel, and behave toward each other (Kirst-Ashman \& Hull, 2014). Relationships may be cooperative, friendly and helpful, or hostile and strained, depending on individuals' patterns of interaction (Zastrow \& KirstAshman, 2012). The relationships within a workplace should comprise the creation of an atmosphere of trust, mutual respect and cooperation among the social workers. As well as fair treatment, these relationships should strengthen the sense of belonging to the organization, coordinate the efforts of social workers tocreate an atmosphere conducive to good performance, enable members to cooperate to achieve the best results possible and provide social, psychological and economic fulfilment. According to Park, if social workers have favorable attitudes and relationships toward each other, their practice becomes more efficient and productive (2014). These relationships arise spontaneously as a result of an interaction of social workers within an organization. Gilligan argues that theinterpersonal relationships at work have a significant relationship to the worker's performance (1988, as cited in Hardina, Middleton, Montana \& Simpson, 2007). The framework applied in this research to explore the human relationships factortakes account of the following attitudes: the organization provides a means of comfort and reassurance for all social workers; there is a positive and meaningful interaction among the social workers; the manager is interested in human relationships;social workers feel comfortable with each other; there is an atmosphere of appreciation and respect among socialworkers; a new socialworker is supported to enhance relationships.

\section{Third: the relationshipbetween the social worker and the manager}

In Libya, generally speaking, managerialpositions are not based upon criteria such as qualifications, years of experience, or length of service. Rather, these positionsare offered as social status given by the hierarchy within an organization. Nevertheless, in Libyan social organizations and rehabilitation centers, it is stilltheusual practice to appoint managers from the field of social work. However, a social worker who is appointed to a managerial position will work as a manager rather than also continuing in a frontline social work role (Shanks et al., 2015).Due to rampant violence in Triploi during collection of data, there were ongoing absences from workplaces, particularly amongst female staff. This has led to a predominance of male workers taking on managerial roles since 2011.The manager's focus will be on everyday administration, employment, and the supervision of employees and they willgenerally have very limited direct contact with residents (McLean \& Andrew, 2011; A. Morgan \& Fraser, 2010). Perhaps the most important two processes undertaken by the manager are to maintain the organizational structures and the implementation of the organization's policies.n his study, published in 2012, Popa considered leadership in human service organizations in a western context. His findings indicate that effective leaders inspire and motivate employees toward improved performance. Indications in developed countries are that leaders develop organizations, inspire the workforce and shape agency culture towards sustainability and performance (Popa, 2012, p.654). By contrast, leadership in Libya is not considered a personal trait of the manager but it is a result of a statutory resolution. The managers are often not prepared with adequate leadership skills. Libyan social workers, like social workers in many countries who move into managerial positions without leadership training and education have less than adequate mentoring (Stoesz, 1997). In this study, the term manager will be used for the head or executive officerwithin an organization. Therefore, this research will consider the leadership role undertakenby the manager.

The framework applied in this research to explore the relationshipbetween social workers and managers explores the following attitudes: the manager collaborates with socialworkers in matters of work; the manager gives social workers full freedom in termsof professional practice; the manager holds meetings to discuss the social workers' problems; the manager works on resolving the social workers' problems fairly; the manager ensures an atmosphere of appreciation and respect with the social workers; the manager appreciates and 
praises good performance; the manager ensures that channels of communication between social workers andthe manager are direct.

\section{Fourth: organizational control}

Anorganization as a controlsystem (Day, 1981) is organized in a hierarchical structure. It has been proposed that all social organizations and rehabilitation centers follow the Weberian model of bureaucracy (Lohmann \& Lohmann, 2002)and that all adhere at least to some of its elements, such as: rules, a hierarchy of authority, appointment and promotion, andformal social relationships (Pardeck, 1996). DuBrin suggests that a manager's work is to control (2013), therefore, an organizational control system is based on the manager influencing social workers by controllingtheir professional practice, in order to ensure the achievement of their compliance, which in turn ensures thatthe objectives of the organization are achieved (Payne, 2002). This form of governance can be considered top-down (Ife, 2009). The framework applied in this research to exploreorganizational control explores the following attitudes:an organization provides opportunities to strengthen ties and relationshipsamong social workers; administrative procedures help to perform work efficiently; the manager is keen to apply the rules and regulations provided by higher authorities; the manager appliesa style of justice based on a reward and punishment system among social workers; rules and regulations are appropriate to ensure professional practice;the organization provides sufficient information to perform the duties required; the manager is interested in the views of social workers on the development of professional practicestandards in the organization.

\section{Research purpose}

This research is significant because there has been to date no research on social workers' professional practice withinsocial organizations and rehabilitation centers in Libyan society. It is important to better understand how leadership operates within such organizations and how governance is conducted (Yoo, 2002; Patti, 2003; Poertner, 2006). Social workers are a valuable resource in social organizations and rehabilitation centers in Libyaand play a crucial role in rendering quality of service to clients.Theyspend the majority of their daily work time in direct practice with clients. Hence the question to be considered is: What impact do the four factors considered above have on the practice of social workers as well as on the performance of human service organizations in Libya? Exploring these four factors could have implications for social workers more broadly and their levels of professional practice.

\section{Method \\ Research design}

This research usesadescriptive exploratory design (Marlow, 2011)based on a questionnaire developedspecifically for a Libyan context and related appropriately to the current research question and aims (Masud, 1999).Whilst a survey technique has been used, the research is qualitative in nature.A phenomenological approach has been taken to interpret the results as they are concerned with how Libyan social workers make sense of their experience in a professional practice context (Braun \& Clarke, 2013; Denzin \& Lincoln, 2011).

\section{Instrument}

The questionnaire consists of a total of 30 items. It begins with four demographic questions onage, gender, place of birth and length of experience as a social worker, but retains anonymity by notnaming the place of employment. In terms of place of birth, 'city' refers to an urban area or municipality of more than 5,000 inhabitants, 'town' is less than 5000 inhabitants, and $88 \%$ of the population of Libya lived in a 'city' or urban area in 2012 (General Information Authority, 2015).Social workers' morale is explored in six items, human relationships in the organization are considered insix items, the questionnaire explores the relationshipbetween social worker and manager within the organization usingseven items and explores the organizational control ina further seven items. The questions were framed using a 4-point Likert scale. These items were used in a previous study (Masud, 1999) but a number were adapated to more effectively suit the current piece of research.Academic staff in the departments of social work, sociology, psychology and management at Tripoli University commented on the appropriateness of these items for use in the manner intended.The questionnaire was provided to social workers in Arabic and results were translated into English by one of the researchers.

\section{Sample and Participants}

This study considered a sample of social workers from four residentialsocial organizations and six residential and day care rehabilitationcenters for handicapped clientswhich are part of the Public Authority for Social Solidarity Fundin the city of Tripoli, the capital of Libya. The Social Solidarity Fund includes 16 branches spread over several Libyan cities.These organizations and centers employ179 social workers, 79 in the social 
organizations and 100 in the rehabilitation centers. There are no data on the total number of social workers employed in Libya.These organizations and centers include a high number of residential clients. The research used a sample of $\mathrm{N}=111$ social workersoutof the total sample of 179 social workers $(62.0 \%)$, based both on social workers having direct contact with theresidents that these social organizations and rehabilitation centers served as well as theirwillingness to participate by completing the questionnaire.

\section{Data Collection and Analysis}

Respondentsfilled in a self-completion questionnaire. Data collection was carried out between July and September 2015. Data were manually analyzed.Content analysis was performed on the survey data (Flick, 2006, p.312) to better comprehend the perspective provided by Libyan social workers. The following formulas were used in the data analysis (Hammadi, 2008): Weighted mean, $x_{w}=\left(n_{i} x_{i}+n_{j} x_{j}\right) / N$; Percentage weighted = $\left(x_{w} / N\right)(100)$; where $x_{w}=$ weighted mean; $x_{i}$ and $x_{j}=$ frequencies of occurrence; $n_{i}$ and $n_{j}=$ responses to questions; andN = total sample size. Weighted mean and percentage weighted were used to differentiate the divergence in the responses between the different sources of data (social organizations and rehabilitation centers) to determine valuing and ranking of each item within each domain. According to Torra, weighting the data provides a 'multicriteria decision-making' process which more effectively balances different information sources(Torra, 1997, p.153; Meier, 1953; Bland \& Kerry, 1998.

\section{Findings}

The gender composition of the participants was60.4\% female and $39.6 \%$ male. The participants indicated that $22.5 \%$ of the respondents were between 25 and 34years of age, $46.8 \%$ between 35 and 44 years and $30.6 \%$ of the participants were older than 45 years, the average of the participants'age being 39 years old. The participants'data show the place of birth as thefollowing: the majority of social workers $(82.9 \%)$ were born in a city.The remaining participants $(17.1 \%)$ were born in a town. This corresponds moderately closely to the distribution of the population in that, in 2010, 88.2\% lived in 'cities' and $11.8 \%$ lived in 'towns' (General Information Authority, 2015).In terms of the social workexperience of the 111 respondentsin this research,27.0\% had been employed as a social worker for one year or less and almost half of them (41.4\%) between two years and six years. Specifically, more than two-thirds of respondents had less than 6 years' experience, and this percentageconfirms a broader trendof the increase in the recruitment of social workers since 2013. Only $18.0 \%$ had experiencedbetween seven years and eleven years employment. And a further $13.5 \%$ had more than 12 years' experience as social workers. Practitioners' years of experience working as social workers ranged from one year to 35 years. The average length of experience as a social worker was 11.8 years.

\section{(Insert Table 1 here)}

To interpret the current research results, the weighted mean and percentage weighted were used to identify, value and rank each item. The weighted mean provides useful information about respondents' attitudes within each of the four factors which were ranked and interpreted from highest to lowest.

\section{(Insert Table 2 here)}

In the state of morale as it related to social work professional practice reflected in Table 2 , the respondents' attitudes toward the cooperation and understanding among them was the highest ranked with weighted mean (1.76) and percentage weighted (88.2). In the social organizations and rehabilitation centers, cooperation benefits the social workers and becomes a source of improving the social workers' performance. This reflects the respondents' conviction that the work routine and boredom ranked second with weighted mean (1.70) and percentage weighted (85.1). Respondents agreed that their satisfaction with the regulations and instructions was worthwhile with weighted mean (1.60) and percentage weighted (80.1). Similar to respondents' attitudes, the job satisfaction had a weighted mean (1.59) and percentage weighted (79.7), while most of the respondents would be willing to move to another workplace with weighted mean (1.58) and percentage weighted (79.2) respectively. However, incentives to improve practice were ranked lowest with weighted mean of (1.20) and percentage weighted (60.3). This possibly indicates that organizations are not providing sufficient financial incentives to encourage their members to remain.Although they may be dissatisfied with several aspects of practice related to their professional practice conditions, lower levels of lack of professional accomplishment and level of role clarity meant that $58.6 \%$ of the respondents reported often thinking about leaving when an opportunity became available to them.

\section{(Insert Table 3 here)}

Human relationships related to social work professional practice reflected in Table 3indicate that a positive and meaningful interaction among the social workers ranked first with weighted mean (1.82) and percentage weighted (91.4). However an atmosphere of appreciation and respect among social workers obtained 
the lowest weighted mean(1.18) and percentage weighted (59.0). Thefact that the social workers feel comfortable with each other is ranked in the second place in terms of the weighted mean (1.52) and percentage weighted (76.1). This was followed by the organization provides means of comfort and entertainment for all social workers, a new social worker is provided help to enhance relationships and the manager is interested in human relationships in terms of weighted means (1.45, 1.30 and 1.18 respectively) and percentage weighted (72.9, 65.3 and 59.0 respectively). The majority of respondents felt that colleagues respected their role as a social worker.

\section{(Insert Table 4 here)}

In Table 4, an atmosphere of appreciation and respect between manager and social workers ranked first in terms of the weighted mean (1.84) and percentage weighted (92.3). This was followed by the manager appreciates and praises a good performance in terms of weighted mean (1.75) and percentage weighted (87.8). The manager discusses with social workers in matters of work ranked the third with weighted mean (1.72) and percentage weighted (86.4), followed by channels of communication between social workersand manager are simple, with weighted mean (1.96) and percentage weighted (84.6).The manager worked on resolving the social workers' problems fairly ranked the fifth with weighted mean (1.64) and percentage weighted of (82.4). The manager held meetings to discuss the socialworkers' problems was placed at the sixth rank with weighted mean (1.38) and percentage weighted (69.3). On the other hand the manager gives social workers full freedom in the way of work performance became the least rated among the items with weighted mean (1.26) and percentage weighted (63.0).

\section{(Insert Table 5 here)}

With regard to the organizational control related to social workers' professional practice, as shown in Table 5, the highest rank was that the manager is keen to apply the rules and regulations as provided by higher authorities with weighted mean (1.80) and percentage weighted (90.0), which was interpreted as strongly related to organizational control. The second ranked are that the rules and regulations are appropriate to provide good performance and the organization provides sufficient information to perform the duties of the work with weighted mean (1.75) and percentage weighted (87.3). This was followed by the administrative procedures help to perform work efficiently with weighted mean (1.73) and percentage weighted (86.4). The lowest ranked were the manager appliesa justice style based on a reward and punishment system among social workers and the manager is interested in the views of social workers on the development of performance standards in the organization with weighted mean (1.61) and percentage weighted (80.6).

\section{(Insert Table 6 here)}

Comparing each of the factors, organizational control has the strongest relationship to professional practice of social workers with percentage weighted (85.27). This is followed by the relation with the manager with percentage weighted (80.82). In the third rank was the state of morale with percentage weighted (78.76), and the lowest was the human relationships with a percentage weighted (71.13).

\section{DISCUSSION AND ANALYSIS}

The objective of this research was to explore four factors around professional practice related to social workers employed in the social organizations and rehabilitation centers in Tripoli. The factor of human relationships between social workers ranked in last place. This might be viewed as surprising given the core values of Libyan traditional culture. There was little difference between the relationship with the manager and social workers' morale, which ranked as the second and third related to social workers' practice respectively.The issue of organizational control ranked in first place as the strongest factor related to social workers' practice. The results could be interpreted to indicate that there was less significance placed onhuman relationships among social workers and there wasgreater pressure placed on them in terms of organizational control.

Human Relationships

The current research reported that there are multiple factors that lead towards poor human relationships amongst social workers' in their professional practice systems, such as: the state of morale, job satisfaction, not belonging to work groups, the relationship with the manager, not holding meeting agendas around the discussion and resolution of problems with social workers, the organization's failure to meet the needs of its workers, poor physical working conditions, working in deplorable offices, and the physical environment that had an effect on their interpersonal interactions. Human relationships exist between social workers as a result of both formal and informal interactions in the workplace. Positive interactions enhance professional practice. On the other hand, negative social behaviors associated with social workers feeling uncomfortable with each other and there being a lack of appreciation and respect among members lead to poor professional practice. New social workers often 
face a lack of informal interaction and meet some difficulties in enhancing their relationships with entrenched social workers. Integration can be determined by the social acceptance experienced within different organizational groups or between members and may appear in the degree of the interaction between a new social worker and colleagues inside and outside the organization. Louis proposed that the new workers must be supported to learn, understand and make sense of the organization and their new position (as cited in Gruman, Saks \& Zweig, 2006), and they are likely to look toward more experienced social workers for direction on how to perform their practice. A suggestion would be to develop policies and provide instruction that guide workers' practice in this area (Latting, 1991).

\section{Social Workers' Morale}

Some of the factors that may help to define employees' morale are job satisfaction, work meaningfulness and work pride (McKnight, Ahmad \& Schroeder, 2001). Interestingly, a significant number of Libyans have more than one source of income, which would indicate that the motivation for employment includes more than afinancial incentive and may lead toconsideration that social workers' morale is not directly related to theorganization which employs thembut rather is more related to their personal prestige or maybe their personal position in the workplace.This issue would need to be clarified in further research. It is the authors' view that social workers in Libya bear the greatest burden in achieving an organization's goals. Dissatisfaction in an organization seems to be a sufficient factor to engender low morale and is associated with an intrinsic willingness to move to another workplace by practitioners, a willingness which is consistent with their view that the nature of the work is routine and boring. These findings support the premise that the social workers' morale in the organization is strongly affected by the level of job satisfaction. On the other hand, the attitudes of social workers in relation to the nature of work as being routine and boring may be based on the assumption that social workers are regularly charged with responsibilities and tasks that are not relevant to their field of specialization. Therefore, the low morale gives an indication of their level of frustration in organizational settings. Some negative phenomena are commonly observed across social organizations and rehabilitation centers, such as indifference and carelessness in the performance of professional practice, late arrival to work, absence without permission and without any valid reasons, and a willingness to move to another workplace. Further to this are negative feelings toward an organization and colleagues, a feeling of job dissatisfaction, lack of stability and decreased sense of job security within the organization. Lack of incentives enhance the social workers' convictions that the organization does not distinguish between workers on the basis of effectiveness and are not interested in social workers practising efficiently. It seems most likely that these convictions can lead to the existence of some negative attitudes and behaviors towards administration and the organization (Penna, Paylor \& Soothill, 1995). This research confirms that there is a relationship between performance and incentives, and that the social workers contribute their professional practice in exchange for salary but alsopraise from the organization. Whenever there is an increase in incentives, this will enhance their satisfaction, which will be reflected in the effectiveness of their professional practice.

\section{Relationship with the Manager}

When a Libyan social worker enters a social organization or rehabilitation center, that social worker has an expectation and perception of his or her relationship with the manager. The manager's responsibilities are mainly focused on performing administrative tasks and ensuring the consistency of performance of the workers as defined by the management system of the organization. The most prevalent kind of relationship in Libya is that the manager takes an authoritarian role within the organization and that the style of leadership is nonconciliatory. Responses indicate that the manager formally discusses matters of work and practitioners indicate that they do not have full freedom to conduct their professional practice. These results give a clear indication that work constraints are evident and include bureaucratic and professional constraints. The responses indicate that the manager restricts performance by controlling social workers' practice at the expense of professional discretion. This can be considered as a type of interference in the social workers' role and may be interpretedas a lack of trust in the capability of social workers to fulfil their practice effectively. On the other hand, there is some evidence which points to the emergence of different types of relationships with the manager. Indeed, $75.0 \%$ of practitioners indicate that they appreciate and respect the manager when the manager praises good performance. The small size of some organizations as well as the number of the social workers employed may contribute to building direct personal interaction with the manager. This interaction may allow the emergence of an interpersonal relationship between manager, colleagues and residents.

\section{Organizational Control}

The way in which information and decisions are transferred within an organization is significant in terms of organizational control. In fact, the results of the current research show that official communication is not the only form of communication within an organization but that informal communication also exists and 
often provides a rapid spread of information. The manager is the key to effective communication channels, and information transfer often depends on the proximity of management to staff. The organization's hierarchy of authority generally contains a formal control system of governance whose purpose is to ensure that there is compliance and submission of workers using both organizational control as well as legislation. Some studies indicatethat thiscan result in an incompatibility between bureaucratic and professional norms (Roach Anleu, 1992). In this view, to achieve control of the organization, the manager uses rules and regulations to control workers at their own discretion (Lambley, 2009). The manager often usesthis control and power for his own benefit. In Libya,this absolute control is formulated by the state and is included in the organizational rules and reporting lines within the organization.However, the frequent intervention by central authorities is often counterproductive to the establishment of effective communication channels. It is reflected in a strategy based on the absolute control, command and domination imposed by the manager to support and maintain his position. This absolute control is a managerial model associated with centralized decisions and the making of orders which flow only in one direction (DuBrin, 2013). Practicing such control does not motivate workers, it reduces morale and it does not ensure their loyalty. This may lead to a situation in which social workers have a sense of deprivation because they have less room to participate in organizational decision making and may prevent them from achieving good performance in their professional practice (Acker, 2003). Responses from this study indicate thatsocial workers prefer to be given the freedom and flexibility to undertake their practice and greater autonomy within the organization.Fear of upper management was palpable in this study. The social workers experienced a lack of professional autonomy, less space for them to make decisions on their own and to choose how to perform their practice. Indeed, $80.2 \%$ of the respondents also indicated that higher authorities imposed restrictions on the manager. This means thatpractices within an organization may be outside the manager's control and, in most cases, include political interference in the social work profession (Ioakimidis, 2013).It also means that the social workers' practices have been directly influenced by changes in the policy outlook of the social organization (Howe, 2002) and changes in the way of thinking about professional practice (Healy, 2000).Mostly respondentsindicated their dissatisfaction with such regulations, especially the lack of suitable regulations relevant to their practice.

\section{General Comments}

The present research emphasizes the importance of communication and collaboration between social workers in social organizations. Poor human relationships, low morale, inadequate relationships with managers and domineering or ineffective organizational control can result in social workers' attention turning primarily to their own interests and personal benefit at the expense of work performance. At times, it would appear that the respondents seemed to operate in their professional roleswithout working collaboratively as a group within their organization, which is in contradiction to some research perspectives (Gibelman, 2000; Scott, 2007; Zastrow, 2014). Perhaps not surprisingly,respondents' practice was often influenced by informal group members' behavior.Interestingly, according to Homans (2010), if the frequency of interaction between two or more personsincreases, the degree of their liking for one another will increase, with the implication that the degree of potential similarity in their professional practice will increase. This would imply that if the social workers in the current study interacted more frequently, encouraged by formal or informal leadership within the organizational structure, then their professional practice may align more closely and more effectively. To improve the practice performance of social workers in social organizations and rehabilitation centers, it is essential to develop the standards of organizational performance(Bradley \& Sutherland, 1995; Samantrai, 1992). The higher the professional practice of social workers, the higher will be the quality of the services that residents will receive. In this respect, it is necessary to design continuing educational programs to improve the practice performance of social workers in organizations in Libya. In particular in this study, social workers' relationships with their colleagues had the highest impact on professional practice and indicate that social organizations and rehabilitation centers need to encourage interaction among social workers.In addition, the type of organizational control provided by managers can improve professional practice. In that respect, it would be helpful to provide clear guidelines of control to managers in order to develop the professional practice of social workers.

The increase of professional identity amongst social workers could be considered as one of the ways in which to increase enjoyment of their job related sense of well-being (Healey \& Hays, 2012).As Libyan social workers better understand their professional identity, this would contribute to improving the social organizations and rehabilitation centers in which they work. Building a rewards support system for social workers would be helpful in solving professional practice related challenges for social workers within Libyansocial organizations and rehabilitation centers.

\section{Limitations}

The current research has several limitations. This research was exploratory and did not capture all the factors related to the professional practice of social workers in Libyansocial organizations and rehabilitation 
centers.Conducted as a content analysis, it would now be beneficial to do further in-depth investigations with a selection of these social workers to gain a richer perspective on the four factors considered. The sample was drawn from only one city, Tripoli, so the results of this research cannot be generalized.A comparative study between Libya and a politically more stable nation, such as Australia, would also be beneficial. Despite limited generalizability, the results from the current exploratory research are interesting and could prove useful to administrators and social workers. Further research more broadly in Libya and in other international settingswould help to confirm these findings.

\section{CONCLUSION}

As mentioned at the beginning of this study, human service organizations can enhance a sense of staff members' own commitment and dedication but also constrain them 'from serving their clients in accordance with their professional and personal norms and values' $(2010, \mathrm{p} 11)$. In terms of Libya, due to the years of political turmoil which have racked the country, the increasing complexity of social workers' work environments has meant that the constraints imposed by the organizational structure in which they operate have made their professional lives more challenging. Indeed, the challenge for both social workers and managers has been to effectively manage the expectations of their clients whilst alsodealing with government regulations, restrictions and control.The research purpose in this study was to explore four factors around professional practice related to social workers employed in the social organizations and rehabilitation centers in Tripoli. The study indicated that organizational control was the prominent concern in the mindsof Libyan social workers, followed by their relationship with their managers, social workers' morale and finally human relationships between social workers. Although there are some issues which are unique to a society such as Libya, other matters are more universal for social workers. This study identifies some problems for social workers more generally arising from factors related to social workers' practice such as: constraints imposed by a centralized authority and the controlling style of managers; organizational control in the organizations and centers; and possible reasons for lack of motivation among social workers, including low morale, andnegative personal relationships between social workers themselves and the manager. Strong and conciliatory leadership and sound governance are important in the operation of social organizations, as well as to enable more effective interaction between social workers themselves and with their manager (Popa, 2012).According to a human relations approach to human service organizations, 'the underlying assumption is that organizational effectiveness is a function of the complementarity and congruency between the goals of the organizations and the personal needs of the workers' (Garrow \& Hasenfeld, 2010, p.35).However, it is also important to understand human service organizations as part of a broader system within the cultural, social and political context, particularly in a developing nation such as Libya. The bureaucratic rules and regulations within workplaces coming from an inflexible cultural context allow its social workersonly a small amount of discretion, autonomy and flexibility. The findings from this study show that the social organizationsand rehabilitation centers in Libya lack ageneral atmosphere of respect and confidence for social workers, even though it was felt that social workers play a significant role in their structure and operation. It was felt that this is mainly due to political influences. A beneficial change would be to reduce the influence of politics within the organizational structureof such organizations, as much as possible,to enhance their organizational effectiveness and so toenable social workers to more effectively implement their professional practice. Popa notes that, 'Leadership is an important catalyst to organizational cohesion that directly translates to effectiveness of service delivery' (2012, p.655). As he says, it is leaders who develop organizations, inspire the workforce and enable change to take place. Effective leadership in human service organizations is critical to the professional practice of social workers.

\section{REFERENCES}

[1] AASW (2013). Australian Association of Social Workers' Practice Standards, 2013. Canberra: AASW

[2] Acker, G. (2003). Role conflict and ambiguity: Do they predict burnout among mental health service providers? Social Work in Mental Health, 1(3), 63-80.

[3] Austin, D. M. (2002). Human Services Management: Organizational leadership in social work practice. New York: Columbia University Press.

[4] Barsky, A. E. (2010). Ethics and values in social work: An integrated approach for a comprehensive curriculum. Oxford: Oxford University Press.

[5] Benish, A. (2010). Re-bureaucratizing welfare administration. Social Service Review, 84(1), 77-101.

[6] Bland, J. M. \& Kerry, S. M. (1998). Weighted comparison of means. British Medical Journal, $316,129$.

[7] Bogo, M. (2006). Social work practice: Concepts, processes and interviewing. New York: Columbia University Press.

[8] Bradley, J. \& Sutherland, V. (1995). Occupational stess in social services: A comparison of social workers and home help staff. British Journal of Social Work, 25(3), 313.

[9] Braun, V. \& Clarke, V. (2013). Succcessful Qualitative Research. London: Sage Publications. 
[10] Bureau of Statistics and Census (2010). Statistics Book. The Libyan Government Transition, Ministry of Planning, Bureau of Statistics and Census and Yearly Bulletin. Accessed data 2016 at: www.bsc.ly.

[11] Calma, T. \& Priday, E. (2011). Putting Indigenous Human Rights into Social Work Practice. Australian Social Work, 64(2), 147-155.

[12] Collins, S. (2008). Statutory Social Workers: Stress, job satisfaction, coping, social support and individual differences. British Journal of Social Work, 38(6), 1173-1193.

[13] Day, P. J. (1981). Social Welfare: Context for social control. Journal of Sociology \& Social Welfare, 8(1), 29-44.

[14] Denzin, N. K. \& Lincoln, Y. S. (2011). Sage Handbook of Qualitative Research, $4^{\text {th }}$ ed. Thousand Oaks, CA: Sage Publications.

[15] DuBrin, A. J. (2013). Leadership: research findings, practice and skills, $7^{\text {th }} e d$. Mason, OH: Cengage Learning.

[16] Flick, U. (2006). An Introduction to Qualitative Research. London: Sage Publications.

[17] Fook, J. \& Gardner, F. (2007). Practising Critical Reflection: A resource handbook. Maidenhead: Open University Press.

[18] Garrow, E. \& Hasenfeld, Y. (2010). Theoretical Approaches to Human Service Organizations. In Human Services as Complex Organizations, $2^{\text {nd }} e d$, by Y. Hasenfeld. Thousand Oaks, CA: Sage Publications, pp.33-58.

[19] General Information Authority (2008). The final results of general census of population, 2006. Tripoli: General Authority of Information.

[20] General Information Authority (2015). Libyan Guide to National Indicators, Phase One: Establishing national indicators. Tripoli: General Information Authority.

[21] Gibelman, M. (2000). What social workers do. Washington: National Association of Social Workers.

[22] Ginsberg, L. H. (2008). Management and leadership in social work practice and education. Alexandria, VA: Council on Social Work Education.

[23] Gruman, J. A., Saks, A. M. \& Zweig, D. I. (2006). Organizational socialization tactics and newcomer proactive behaviors: An integrative study. Journal of Vocational Behavior, 69(1), 90-104.

[24] Hammadi, Y. (2008). Social Statistics (in Arabic). Al-Zawiya, Libya: The Seventh of April University Press.

[25] Hardina, D., Middleton, J., Montana, S. \& Simpson, R. (2007). An empowering approach to managing social service organizations. New York: Springer.

[26] Hasenfeld, Y. (2010). The Attributes of Human Service Organizations. In Human Services as Complex Organizations, $2^{\text {nd }}$ ed, by Y. Hasenfeld. Thousand Oaks, CA: Sage Publications, pp.9-32.

[27] Healey, A. C. \& Hays, D. G. (2012). A discriminant analysis of gender and counsellor professional identity development. Journal of Counselling and Development, 90(1), 55-62.

[28] Healy, K. (2000). Social work practices: Contemporary perspectives on change. London: Sage.

[29] Homans, G. C. (2010). The human group. New York: Routledge.

[30] Howe, D. (2002). Surface and depth in social work practice. In P. Nigel (ed.), Social theory, social change and social work, pp.77-97. New York: Routledge.

[31] Ife, J. (2009). Human Rights from Below: Achieving Rights through Community Development. London: Cambridge University Press.

[32] Iokamidis, V. (2013). Beyond the dichotomies of cultural and political relativism: Arguing the case for a social justice based 'global social work' definition. Critical and Radical Social Work, 1(2), 183-199.

[33] Itzin, C. \& Newman, J. (2005). Gender, culture and organizational change: Putting theory into practice, $3^{\text {rd }}$ ed. London: Routledge.

[34] Iversen, R. R. (2004). Voices from the middle: How performance funding impacts workforce organzations, professionals and customers. Journal of Sociology and Social Welfare, 31(2), 125-156.

[35] Johnson, L. C. \& Yanca, S. J. (2010). Social work practice: A generalist approach, $10^{\text {th }}$ ed. Boston: Allyn \& Bacon.

[36] Kadushin, A. \& Harkness, D. (2014). Supervision in social work, $5^{\text {th }}$ ed. New York: Columbia University Press.

[37] Kirst-Ashman, K. (2013). Human behavior in the macro-social environment: An empowerment approach to understanding communities, organizations and groups, $4^{\text {th }} \mathrm{ed}$. Belmont, CA: Thomson Brooks/Cole.

[38] Kirst-Ashman, K \& Hull, G. (2014). Generalist practice with organizations and communities, $6^{\text {th }} \mathrm{ed}$. Stamford: Cengage Learning.

[39] Kondrat, M. E. (2002). Actor centred social work: Re-visioning 'person in environment' through a critical theory lens. Social Work, 47(4), 435-448.

[40] Lambley, S. (2009). Proactive management in social work practice. Exeter: Learning Matters. 
[41] Latting, J. K. (1991). Eight myths on motivating social service workers: Theory based perspectives. Administration in Social Work, 15(3), 49-66.

[42] Lohmann, R. \& Lohmann, N. (2002). Social Administration. New York: Columbia University Press.

[43] Marlow, C. (2011). Research methods for generalist social work. Belmont, CA: Thomson Brooks/Cole.

[44] Mascha, K. (2007). Staff morale in day-care centers for adults with intellectual disabilities. Journal of Applied Research in Intellectual Disabilities, 20(3), 191-199.

[45] Masud, A. (1999). Applied study of some factors that related to employees' performance system in social welfare organizations in Tripoli (in Arabic). Unpublished thesis, University of El-Fateh.

[46] Masud, A. (2011). Values in practice: Exploring the interplay between personal values and professional values of social work in Libya. Unpublished dissertation, School of Social and Policy Studies, Flinders University, Australia.

[47] McKnight, D., Ahmed, S. \& Schroeder, R. (2001). When do feedback, incentive control and autonomy improve morale? The importance of employee-management relationship closeness. Journal of Mangerial Issues, 13(4), 466-482.

[48] McLean, J. \& Andrew, T. (2011). Commtiment, satisfaction, stress and control among social services managers and social workers in the UK. In M. Barak \& D. Bargal (eds.), Social services in the workplace repositioning occupational social work in the new millennium (pp.93-117). New York: Routledge.

[49] Meier, P. (1953). Variance of a Weighted Mean. Biometrics, 9(1), 59-73.

[50] Michael, L. S. \& Femida, H. (2015). Social change efforts of direct service nonprofits: The role of funding and collaborative networks in shaping social innovations. Human Service Organizations, 39(1), 6-24.

[51] Morgan, A. \& Fraser, S. (2010). Looked after young people and their social work managers: A study of contrasting experiences of using computer assisted self-interviewing (A-CASI). British Journal of Social Work, 40(2), 445-461.

[52] Morgan, G. (2010). Images of organization. Thousand Oaks, CA: Sage Publications.

[53] Pardeck, J. T. (1996). Social work practice: An ecological approach. Westport, CO: Auburn House.

[54] Park, M. (2014). Job satisfaction of social workers in senior welfare centres in South Korea: The effects of individual, client and organizational factors. Asia Pacific Journal of Social Work and Development, 24(3), 184-195.

[55] Patti, R. (2003). Refelctions on the state of management in social work. Administration in Social Work, 27(2), 1-11.

[56] Payne, M. (2002). Management. In R. Adam, L. Dominelli \& M. Payne (eds.), Practising social work in a complex world (pp.223-235). Houndsmill: Palgrave.

[57] Payne, M. (2009). Management and managerialism. In R. Adam, L. Dominelli \& M. Payne (eds.), Practising social work in a complex world, $2^{\text {nd }}$ ed. (pp.143-157). Basingstoke: Palgrave Macmillan.

[58] Penna, S., Paylor, I. \& Soothill, K. (1995). Job satisfaction and dissatisfaction: A study of residential care work. London: National Institute for Social Workers.

[59] Poertner, J. (2006). Social administration and outcomes for consumers: What do we know?Administration in Social Work, 30(2), 11-24.

[60] Popa, A. B. (2012). A quantitative analysis of perceived leadership practices in child welfare organizations. Journal of Public Child Welfare, 6(5), 636-658.

[61] Rank, M. G. \& Hutchison, W. S. (2000). An analysis of leadership within the social work profession. Journal of Social Work Education, 36(3), 487-502.

[62] Rauktis, M. E. \& Koeske, G. F. (1994). Maintaining social worker morale: When supportive supervision is not enough. Administration in Social Work, 18(1), 39.

[63] Roach Anleu, S. (1992). The professionalization of social work? A case study of three organizational settings. Sociology, 26(1), 23-43.

[64] Samantrai, K. (1992). Factors in the decision to leave: Retaining social workers with MSWs in public child welfare. Social Work, 37(5), 454-458.

[65] Schmid, H. (2004). Organization-environment relationships: Theory for management practice in human service organizations. Administration in Social Work, 28(1), 97-114.

[66] Scott, W. R. (2007). Organizations rational, natural and open systems, $5^{\text {th }}$ ed. New Jersey: Pearson Education.

[67] Shanks, E., Lundstrom, T. \& Wiklund, S. (2015). Middle managers in social work: Professional identity and management in a marketised welfare state. British Journal of Social Work, 45(6), 1871-1887.

[68] Shier, M. L. \& Graham, J. R. (2013). Subjective well-being, social work and the environment: The impact of the socio-political context of practice on social worker happiness. Journal of Social Work, 15(1), 3-23.

[69] Skyttner, L. (2002). General systems theory: Ideas and applications. Singapore: World Scientific. 
[70] Sowers, K. M. \& Rowe, W. (2007). Social work practice and social justice: From local to global perspective. Belmont, CA: Thomson Brooks/Cole.

[71] Stoesz, B. (1997). The end of social work. In M. Reisch \& E. D Gambrill (eds.), Social Work in the $21^{\text {st }}$ Century (pp.368-375). Thousand Oaks, CA: Pine Forge.

[72] Sue, D. W. \& Sue, D. (2013). Counselling the culturally diverse: Theory and Practice, $6^{\text {th }}$ ed. Hoboken, NJ: John Wiley \& sons.

[73] Teater, B. (2011). An introduction to applying social work theories and methods. Maidenhead: Open University Press.

[74] Tham, P. \& Meagher, G. (2009). Working in human services: How do experiences and working conditions in child welfare social work compare? British Journal of Social Work, 39(5), 807-827.

[75] Thompson, N. \& Thompson, S. (2008). The social work companion. Basingstoke: Palgrave Macmillan.

[76] Torra, V. (1997). The Weighted OWA Operator. International Journal of Intelligent Systems, 12, 153166.

[77] Yoo, J. (2002). The relationship between organizational variables and client outcomes: A case study in child welfare. Administration in Social Work, 26(2), 39-61.

[78] Zastrow, C. (2014). Social work with groups: A comprehensive workbook, $9^{\text {th }}$ ed. Belmont, CA: Cengage Learning.

[79] Zastrow, C. \& Kirst-Ashman, K. (2012). Understanding human behavior and the social environment, $9^{\text {th }}$ ed. Belmont, CA: Cengage Learning.

Tables:

Table 1: Demographic characterstics of sample $(n=111)$

\begin{tabular}{|l|l|l|l|}
\hline Variable & Value Labels & Frequency (n) & Percentage (\%) \\
\hline \multirow{3}{*}{ Gender } & Male & 44 & 39.6 \\
\cline { 2 - 4 } & Female & 67 & 60.4 \\
\hline \multirow{5}{*}{ Place of birth } & $25-34$ & 25 & 22.5 \\
\cline { 2 - 4 } & $35-44$ & 52 & 46.8 \\
\cline { 2 - 4 } & $45+$ & 34 & 30.6 \\
\hline Experience (years) & Town & 19 & 17.1 \\
\cline { 2 - 4 } & City & 92 & 82.9 \\
\cline { 2 - 4 } & $0-1$ & 30 & 27.0 \\
\cline { 2 - 4 } & $2-6$ & 46 & 41.4 \\
\cline { 2 - 4 } & $7-11$ & 20 & 18.0 \\
\cline { 2 - 4 } & $12+$ & 15 & 13.5 \\
\hline
\end{tabular}

Table 2: Factors related to the state of morale

\begin{tabular}{|l|l|l|l|l|}
\hline $\begin{array}{l}\text { Item } \\
\text { No }\end{array}$ & Items & $\begin{array}{l}\text { Weighted } \\
\text { mean }\end{array}$ & $\begin{array}{l}\text { Percentage } \\
\text { weighted }\end{array}$ & Rank \\
\hline 2 & Satisfaction with the regulations and instructions & 1.60 & 80.1 & 3 \\
\hline 6 & Job satisfaction & 1.59 & 79.7 & 4 \\
\hline 14 & The work routine and boredom tedious & 1.70 & 85.1 & 2 \\
\hline 20 & Cooperation and understanding among social workers & 1.76 & 88.2 & 1 \\
\hline 21 & Willing to move to other workplace & 1.58 & 79.2 & 5 \\
\hline 23 & There are incentives encourage to improve practice & 1.20 & 60.3 & 6 \\
\hline \multicolumn{4}{|l|}{ Mean Percentile } \\
\hline
\end{tabular}

Table 3: Factors related to human relationships

\begin{tabular}{|c|c|c|c|c|}
\hline $\begin{array}{l}\text { Item } \\
\text { No }\end{array}$ & Items & $\begin{array}{l}\text { Weighted } \\
\text { mean }\end{array}$ & $\begin{array}{l}\text { Percentage } \\
\text { weighted }\end{array}$ & Rank \\
\hline 5 & $\begin{array}{l}\text { The organization provide means of comfort and } \\
\text { reassurance for all social workers }\end{array}$ & 1.45 & 72.9 & 3 \\
\hline 8 & $\begin{array}{l}\text { There is a positive and meaningful interaction } \\
\text { among the social workers }\end{array}$ & 1.82 & 91.4 & 1 \\
\hline 10 & The manager is interested in human relationships & 1.24 & 62.1 & 5 \\
\hline 12 & Social workers feel comfortable with each other & 1.52 & 76.1 & 2 \\
\hline 15 & id respect among social workers & 1.18 & 59.0 & 6 \\
\hline 22 & $\begin{array}{r}\text { A new social worker is provided help to enhance } \\
\text { relationships }\end{array}$ & 1.30 & 65.3 & 4 \\
\hline \multicolumn{5}{|c|}{ Mean Percentile } \\
\hline
\end{tabular}


Table 4: Factors related to the relationship with the manager

\begin{tabular}{|c|c|c|c|c|}
\hline $\begin{array}{l}\text { Item } \\
\text { No }\end{array}$ & Items & $\begin{array}{l}\text { Weighted } \\
\text { mean }\end{array}$ & $\begin{array}{l}\text { Percentage } \\
\text { weighted }\end{array}$ & Rank \\
\hline 13 & $\begin{array}{r}\text { The manager discusses with social workers in matters of } \\
\text { work }\end{array}$ & 1.72 & 86.4 & 3 \\
\hline 16 & $\begin{array}{l}\text { Gives social workers full freedom in the way of work } \\
\text { performance }\end{array}$ & 1.26 & 63.0 & 7 \\
\hline 17 & Held meetings to discuss the social workers' problems & 1.38 & 69.3 & 6 \\
\hline 18 & Working on resolving the social workers' problems fairly & 1.64 & 82.4 & 5 \\
\hline 19 & $\begin{array}{r}\text { An atmosphere of appreciation and respect between the } \\
\text { manager and social workers }\end{array}$ & 1.84 & 92.3 & 1 \\
\hline 24 & Appreciates and praises a good performance & 1.75 & 87.8 & 2 \\
\hline 25 & $\begin{array}{r}\text { Channels of communication between social workers and } \\
\text { manager are simple }\end{array}$ & 1.69 & 84.6 & 4 \\
\hline
\end{tabular}

Table 5: Factors related to organizational control

\begin{tabular}{|c|c|c|c|c|}
\hline $\begin{array}{l}\text { Item } \\
\text { No }\end{array}$ & Items & $\begin{array}{l}\text { Weighted } \\
\text { mean }\end{array}$ & $\begin{array}{l}\text { Percentage } \\
\text { weighted }\end{array}$ & Rank \\
\hline 1 & $\begin{array}{l}\text { Organization provides opportunities to strengthen } \\
\text { ties and relations among social workers }\end{array}$ & 1.68 & 84.2 & 5 \\
\hline 3 & $\begin{array}{r}\text { Administrative procedures help to perform work } \\
\text { efficiently }\end{array}$ & 1.73 & 86.9 & 4 \\
\hline 4 & $\begin{array}{r}\text { Manager is keen to apply the rules and regulations } \\
\text { were provided by higher authorities }\end{array}$ & 1.80 & 90.0 & 1 \\
\hline 7 & $\begin{array}{l}\text { Manager applies the justice style based on the } \\
\text { reward and punishmentsystem among social } \\
\text { workers }\end{array}$ & 1.61 & 80.6 & 6 \\
\hline 9 & $\begin{array}{r}\text { Rules and regulations are appropriate to provide } \\
\text { good performance }\end{array}$ & 1.75 & 87.3 & 2 \\
\hline 11 & $\begin{array}{r}\text { Organization provides sufficient information to } \\
\text { perform the duties of the work }\end{array}$ & 1.75 & 87.3 & 2 \\
\hline 26 & $\begin{array}{l}\text { Manager interested in the views of social workers } \\
\text { on the development of performance standards in } \\
\text { organization }\end{array}$ & 1.61 & 80.6 & 6 \\
\hline \multicolumn{5}{|c|}{ Mean Percentile } \\
\hline
\end{tabular}

Table 6: Four dimensions related to social workers' professional practice

\begin{tabular}{|l|l|l|l|}
\hline & the domain & $\begin{array}{l}\text { Mean } \\
\text { Percentile }\end{array}$ & $\begin{array}{l}\text { arrang } \\
\mathrm{e}\end{array}$ \\
\hline 1 & The state of morale & 78.76 & 3 \\
\hline 2 & Human relationships & 71.13 & 4 \\
\hline 3 & Relation with the manager & 80.82 & 2 \\
\hline 4 & Organizational control & 85.27 & 1 \\
\hline & the general average & 78.99 & \\
\hline
\end{tabular}

